\title{
Repetitive begjæringer om gjenåpning i straffesaker
}

Av professor emeritus Ulf Stridbeck

Gjenåpning av straffesaker er en ekstraordinær mulighet for å få rettet opp en uriktig dom. Spørsmålet som kan stilles fra et etterlatte- og fornærmede-perspektiv, er hvor ofte og hvor mange ganger en domfelt skal få begjære gjenåpning i samme sak. For noen etterlatte kan det oppleves som en sterk belastning at saken ikke får en slutt, slik at de kan legge denne bak seg og, for noen, få sorgen mer på avstand. Et betimelig spørsmål de etterlatte kan stille, er når er nok nok? Dette reiser spørsmål om hvor mange ganger en domfelt skal kunne begjære gjenåpning i samme sak. Med eksempler fra de nordiske landene peker forfatteren på mulige løsninger på det opplevde problemet.

Nøkkelord: bevis, Gjenopptakelseskommisjonen, gjenåpning, uriktige domfellelser

Ulf Stridbeck er professor emeritus ved Institutt for offentlig rett, Juridisk fakultet, Universitetet i Oslo. Tidligere fagansvarlig for strafferettsundervisningen i Oslo. Stridbeck er redaktør for Tidsskrift for strafferett. Han var leder for arbeidsgruppen som evaluerte Gjenopptakelseskommisjonen. De seneste årene har rettspsykologi stått i fokus for forskningen.

\section{Gjenåpningsgrunnene ${ }^{1}$}

Dersom en person mener seg uriktig domfelt, kan han begjære gjenåpning av den rettskraftige dommen. Gjenåpning er ikke en ekstra ankemulighet. Men hvis noen av gjenåpningsgrunnene foreligger, er gjenåpning en ekstraordinær mulighet for å rette opp en uriktig dom. De mest vanlige grunnene for gjenåpning til gunst for domfelte er nye bevis eller nye omstendigheter «som synes egnet å føre til frifinnelse og som ikke har vært vurdert tidligere», jf. straffeprosessloven (strpl.) § $391 \mathrm{nr}$. 3. ${ }^{2}$ Det stilles altså to krav. Noe nytt må legges fram, og dette nye skal være egnet til å føre til frifinnelse. Vurderingstemaet er betydningen av det nye beviset dersom det hadde foreligget for retten da saken ble pådømt, sett i sammenheng med bevisene som forelå for den dømmende rett.

En enda mer ekstraordinær mulighet er når særlige forhold gjør det tvilsomt om dommen er riktig, og tungtveiende hensyn tilsier at skyldspørsmålet blir prøvd på nytt, jf. strpl. § 392. Lovgivers intensjon er at regelen skal benyttes som en sikkerhetsventil, og med stor varsomhet. Bestemmelsen blir ofte anført som et subsidiært grunnlag for gjenåpning dersom de nye bevisene eller de nye omstendighetene ikke skulle begrunne en gjenåpning. I Rt. 1996 s. 280 uttaler Høyesteretts kjæremålsutvalg at det ikke ligger noen begrensning med hensyn til hva slags «særlige forhold» som kan telle med ved vurderingen av om en fellende dom er riktig. Av Rt. 1996 s. 1018 framgår det at nye elementer som kan belyse saken, må kunne

\footnotetext{
${ }^{1}$ Takk til anonym fagfelle for kompetente kommentarer.

${ }^{2}$ Se Nils Erik Lie, «Vilkårene for gjenåpning etter straffeprosessloven § $391 \mathrm{nr}$. 1, særlig om forståelsen av uttrykkene «ny omstendighet» og «nytt bevis»», Lov og Rett, 2020 s. 293-311.
} 
inngå i en samlet vurdering av om det foreligger «særlige forhold», selv om de isolert sett ikke ville være tilstrekkelige til å begrunne gjenåpning etter $§ 391 \mathrm{nr} .3$.

I norsk rett foreligger ikke noen begrensninger i hvor mange ganger man kan begjære gjenåpning etter at Gjenopptakelseskommisjonen har nektet gjenåpning. Kommisjonens avslag har ingen

rettskraftsvirkning som stenger for en ny begjæring. I Norge har det forekommet at en domfelt person har begjært ny behandling av sin sak etter sju avslag.

Det er heller ikke noen foreldelsesfrister, verken med hensyn til den tid som er gått etter domsavsigelsen, eller med hensyn til den tid som er gått etter at domfelte «fant» det nye beviset eller omstendigheten. Det er mulig å begjære gjenåpning av meget gamle straffesaker. For eksempel er det blitt fremsatt begjæring om gjenåpning av en sak helt tilbake til den tyske okkupasjonen av Norge. Det innebærer at Gjenopptakelseskommisjonen må vurdere hvilken vekt nye bevis har i sammenheng med et bevisbilde som er 50-60 år gammelt. ${ }^{3}$

\section{Gjentagende begjæringer}

Som det framgår av teksten ovenfor, foreligger ingen begrensninger i antallet begjæringer, og heller ikke tidsfrister. Det åpner for at det er mulig å begjære gjenåpning mange ganger.

Etterlatte i noen saker - som Torgersensaken og Baneheiasaken - har gitt uttrykk for at det er en sterk belastning at saken ikke får en slutt, slik at de kan legge denne bak seg og, for noen, få sorgen mer på avstand. Et betimelig spørsmål de etterlatte kan stille, er når er nok nok? Dette reiser spørsmål om hvor mange ganger en domfelt skal kunne begjære gjenåpning i samme sak, og hvor mange ganger en person som begjærer gjenåpning, skal kunne bygge sin begjæring på varianter eller nytolkninger av tidligere vurderte bevis.

Disse spørsmålene har ikke bare et fornærmede- og etterlatte-perspektiv, men også en side mot ressursbruken i Gjenopptakelseskommisjonen. Hver sak krever tid og ressurser ved behandlingen i Kommisjonen, både fra utredere og kommisjonsmedlemmer. Hvis det ikke presenteres en tidligere ukjent «smoking gun», som et nytt bevis som åpenbart fører til gjenåpning, blir begjæringene gjerne mer og mer omfattende for hver gang saken blir sendt inn. Det er ikke uten videre slik at nye begjæringer betyr mindre arbeid for Kommisjonen. Alle begjæringer må i utgangspunktet behandles med samme alvor og grundighet, uavhengig av om det er en gjentatt begjæring eller en førstegangsbegjæring.

Ada Sofie Austegard fra Stine Sofies Stiftelse har i media tatt opp spørsmålet om repetitive begjæringer om gjenåpning fra et fornærmede- og etterlatte-perspektiv til debatt: «Det bør settes en grense for hvor mange ganger en advokat kan melde inn samme sak til Gjenopptakelseskommisjonen.» ${ }^{4}$ Hennes forslag er at det kunne vært en fordel om det ble lagt en demper på «ivrige» advokater. Hun foreslår at etter to begjæringer fra én advokat må en ny advokat fra et annet advokatfirma eventuelt føre saken videre. Forslaget kan tolkes slik at iveren er forsvarerdrevet i den betydning at forsvareren har en egeninteresse i å «vinne saken» mot Gjenopptakelseskommisjonen ved å begjære gjenåpning på nytt etter et avslag.

\footnotetext{
${ }^{3}$ Tiden kan være et problem siden det normalt ikke finnes lydopptak (og bildeopptak) av hovedforhandlingen (Lilandsaken er et sjeldent unntak siden det der fantes «ulovlige» lydopptak fra saken), og hukommelsen til vitner svekkes med tiden, vitner kan være døde, realbevis kan være kastet eller blitt borte, mv.

${ }^{4}$ NRK.no 23. mars 2020: https://www.nrk.no/sorlandet/mener-advokaten-til-viggo-kristiansen-utnyttersystemet-1.14861102.
} 
Arbeidsgruppen som evaluerte Gjenopptakelseskommisjonen i 2011, tok i sin tid opp temaet om gjentatte henvendelser generelt. ${ }^{5}$ Arbeidsgruppen konkluderte med at det ikke burde innføres generelle begrensninger på gjentatte henvendelser.

\section{Mulige grep mot repetitive begjæringer}

\subsection{Filtrering av forsvarere}

Forslaget fra Austegard om å begrense det frie forsvarervalget er å ta mannen og ikke ballen. Hennes forslag om å stoppe «overivrige» forsvarere utfordrer det frie forsvarervalget, som er tungt forankret $\mathrm{i}$ Norge. Å selv kunne velge sin forsvarer har med tillit å gjøre. Den domfelte har rett til å bruke den personen han har mest tillit til. Forsvareren er den domfeltes talerør. Det er likevel begrensninger på hvem som kan føre en sak for Høyesterett. Forsvarerne må få godkjent to prøvesaker for Høyesterett for å få prosedere videre der. Det er viktig for sakens rettslige opplysning at det er de beste juristene som presenterer saken for Høyesterett. Det er imidlertid en vesentlig forskjell mellom hva slags problemstillinger og vurderingstemaer som er sentrale i Høyesterett og i Gjenopptakelseskommisjonen. I Høyesterett skjer det ingen bevisførsel om skyld. Der er det lovanvendelse og saksbehandling som drøftes. Altså stort sett lov og lovtolking. I Gjenopptakelseskommisjonen er det faktum, nye bevis eller omstendigheter som legges fram. Jussen er det sjelden noe problem med. Kunne man ha en lignende godkjennelsesordning for gjenåpningssaker? Kanskje. Men jeg er usikker på etter hvilke kriterier filtreringen i så fall skulle gjennomføres.

\subsection{En absolutt eller relativ tidsbegrensning}

I sivile saker må begjæringen om gjenåpning settes fram innen seks måneder etter at parten ble kjent med det forhold begjæringen bygger på, jf. tvisteloven (tvl.) § 31-6 (1). Saken kan imidlertid ikke gjenåpnes etter ti år, jf. tvl. § 31-6 (2).

Spørsmålet her er om en slik absolutt frist også kan og bør gjelde for straffesaker.

Straffeprosessutvalget mener at det ikke er aktuelt:

«I sivile saker er fristen i hovedsak begrunnet i hensynet til motparten, et hensyn som ikke har samme gjennomslag for straffesaker. Dertil kommer at disposisjonsprinsippet som gjelder for sivile saker i større grad åpner for å stille partene til ansvar for å unnlate å foreta prosesshandlinger. I straffesaker bør sannhetsidealet gis større gjennomslagskraft.» ${ }^{6}$

Ved etterkontrollen av Gjenopptakelseskommisjonen i 2011 ble arbeidsgruppen bedt om å vurdere gjenåpningsadgangen i eldre saker. Problemet med gamle saker hadde tidligere blitt tatt opp av riksadvokaten i en høringsuttalelse i 2006. Riksadvokaten foreslo at det burde være strengere vilkår for dommer over en viss alder. Med den begrunnelse at bevisene i eldre saker ofte vil være svekket, foreslo riksadvokaten at alle saker eldre enn 15 år skulle vurderes etter den strenge formuleringen «meget tvilsomt» om dommen er riktig. Han ble ikke hørt den gang.

Arbeidsgruppen som evaluerte Gjenopptakelseskommisjonen, foreslo en frist for gjenåpning av dommer ved mindre alvorlige straffbare forhold, satt til ti år fra det tidspunkt den fellende dommen ble rettskraftig. Argumentet her var at bevisgrunnlaget i saker må antas å svekkes over tid, samtidig som

\footnotetext{
${ }^{5}$ Etterkontroll av gjenopptakelseskommisjonen, punkt 3.2.9.3. https://www.regjeringen.no/globalassets/upload/jd/vedlegg/rapporter/etterkontroll gjenopptakelse .pdf. Til orientering var forfatteren leder for arbeidsgruppen.

${ }^{6}$ NOU 2016: 24, punkt 22.3.6.5.
} 
viktigheten av gjenåpning ikke er like stor verken for samfunnet eller den domfelte i mindre alvorlige saker. Arbeidsgruppen foreslo et nytt første ledd annet punktum i $§ 389:{ }^{7}$

«Dersom det er gått mer enn ti år siden dommen ble rettskraftig, kan dommen kun gjenåpnes dersom det er idømt strengere straff enn fengsel i 6 måneder eller gjenåpning kan finne sted etter $\S \S 391 \mathrm{nr}$. 1 annet ledd eller 393.»

I høringsuttalelsen til dette forslaget foreslo Gjenopptakelseskommisjonen en høyere terskel for gjenåpning av dommer som har vært rettskraftige i 20 år. $^{8}$

Et enstemmig straffeprosesslovutvalg fulgte, i 2016, verken opp Arbeidsgruppens eller Kommisjonens forslag. På bakgrunn av at saker som ligger langt tilbake i tid, ikke kan behandles på nytt ut fra samme bevismessige betingelser, anbefalte utvalget at man stiller noe strengere vilkår for gjenåpning av eldre dommer. Utvalget foreslo således en generell frist på 25 år, i lovforslaget $§ 41-11:^{9}$

«For avgjørelser som har vært rettskraftige i 25 år, kreves det for gjenåpning etter $\S ~ 41-5$ til 41-10 at det foreligger forhold som gjør det meget tvilsomt at dommen er riktig.»

Forslaget fra Straffeprosesslovutvalget innebærer et krav om høyere terskel etter 25 år. I tillegg til de alminnelige vilkårene for gjenåpning stiller således lovforslaget krav om at det påvises forhold som gjør det meget tvilsomt at dommen er riktig. Ordlyden forutsetter at det utøves et skjønn der de hensyn som måtte tale henholdsvis for og mot gjenåpning av eldre saker, tas i betraktning.

En tidsfrist alene, uavhengig av dens lengde, begrenser imidlertid ikke antallet gjenåpningsbegjæringer av samme sak innenfor tidsrammen.

\subsection{En absolutt eller relativ begrensning av antallet begjæringer}

Det høyeste antall begjæringer i samme sak til Gjenopptakelseskommisjonen så langt er åtte begjæringer. Det gjelder den nå aktuelle Baneheiasaken. Det er færre begjæringer i Torgersensaken, men han har i tillegg begjært gjenåpning i det gamle systemet - til sammen tre til Høyesterett og fire til Kommisjonen. Den seneste begjæringen er ennå ikke behandlet.

Det kan selvfølgelig hende at en sak blir gjenåpnet etter syvende eller åttende begjæring. Et spørsmål som kan stilles da, er hva som manglet ved de tidligere begjæringene siden de ikke nådde fram. Var det nye som ble anført i begjæring 2 til 7, egentlig for «lett», slik at det var «bortkastet» ressursbruk fra domfeltes side? Eller var det først i den siste begjæringen ny vitenskapelig viten ble lagt fram som avgjørende nytt bevis?

Er det klokt og er det mulig å legge inn en prosessuell sperre etter et bestemt antall fors $\emptyset \mathrm{k}$ ? Tanken kunne være at hvis domfelte ikke har klart å presentere overbevisende nye bevis eller omstendigheter som åpenbart fører til gjenåpning etter et visst antall begjæringer, så bør det ikke være lov med flere fors $\varnothing \mathrm{k}$.

En definitiv begrensning av hvor mange ganger man kan fremsette en begjæring, vil etter mitt syn neppe være veien å gå. I stedet bør Kommisjonen akseptere at en domfelt har begjært gjenåpning tidligere, men være oppmerksom på at gjentagende begjæringer trolig bør få en enklere behandling. Inneholder de ikke noe nytt, så skal de forkastes og ikke realitetsbehandles. Fornærmede/etterlatte vil da ikke bli orientert eller trukket inn i saken, jf. § 397 5. ledd jf. 3. ledd.

Men, igjen, det som kan være arbeidskrevende, vil ofte være å skille ut om det virkelig er noe nytt, eller om det er tidligere bevistilbud $i$ «ny forkledning».

${ }^{7}$ Etterkontroll av gjenopptakelseskommisjonen, 4.1.2 Arbeidsgruppens lovutkast.

${ }^{8}$ Gjenopptakelseskommisjonens høringssvar 1. februar 2013 til Høring om rapport om etterkontroll av Kommisjonen for gjenopptakelse av straffesaker 24. oktober 2012, s. 2-3. Sitert fra NOU 2016: 24, s. 468.

${ }^{9}$ NOU 2016: 24, s. 468. Begrunnelsen for akkurat 25 år er imidlertid uklar for meg. 


\section{Nordiske løsninger}

I forbindelse med en nordisk bok om gjenopptakelse som jeg redigerer, har jeg blitt oppmerksom på en interessant forskjell mellom de nordiske landenes praksis, og advokatenes iver hva gjelder begjæringer om gjenåpning.

Repeterende begjæringer om gjenåpning i samme sak finner vi både i Norge og Sverige. I Finland, der det tidligere har vært mange begjæringer, har man tatt noen lovmessige grep for å få ned antallet. Derimot er fenomenet med repetitive gjenåpninger ikke-eksisterende i Danmark.

Finland er det nordiske land som har gått lengst hva gjelder grep mot repetitive begjæringer. ${ }^{10} \mathrm{Et}$ meget stort antall begjæringer om gjenåpning til Högsta domstolen på begynnelsen av 2000-tallet var drivkraften bak senere reformer. Et volum på 380-480 begjæringer per år syntes man var for mye. Reformene hadde således som formål å dempe dette. I dette lå også et ønske om å begrense «mångfaldigt extraordinärt ändringssökande». ${ }^{11}$ Det fantes allerede en mulighet til å ilegge sakskostnader ved unødig prosess, jf. Rättegångsbalken (RB) 21 kap. 6 §:

«Om den ene partens representant, ombud eller fullmektig så som avses i $\S \S 4$ eller 5 forsettlig eller av uaktsomhet har påført motparten saksomkostninger, kan han, sammen med sin oppdragsgiver, bli pålagt å erstatte motparten disse kostnader.»

Bestemmelsen bremser begjæringer om gjenåpning som er omformuleringer, eventuelt med sakkyndiges omvurderinger, av tidligere vurderte bevis.

Men det var tydeligvis ikke nok. Det ble derfor innført fire lovendringer: en om advokattvang i gjenåpningssaker i Högsta domstolen, en om forenkling av rettens sammensetning, en om begrensning i antall begjæringer og til slutt en om delegering av saker om endring av botens størrelse. Hovedregelen er at begjæring om gjenåpning søkes hos Högsta domstolen, jf. RB 31 kap. $12 \S 1$ avsnitt.

Før det første er det innført et krav om å ha advokat ved søknad om gjenåpning. Ifølge RB 15 kap. $1 \S$ 4 avsnitt skal personer som begjærer gjenåpning i Högsta domstolen, bruke advokat. Dette gjelder uansett om vedkommende selv er jurist. ${ }^{12}$

Av den finske regjeringens proposisjon om advokattvang framgår det at det er vanlig med gjenåpningsbegjæringer til Högsta domstolen, men at de sjelden fører fram. I proposisjonen pekes det på at Högsta domstolens begrensede ressurser på denne måten blir brukt til håpløse begjæringer. Tanken bak kravet om advokattvang er at en jurist kan bidra med å sortere bort de håpløse begjæringene. Dessuten burde advokattvang bidra til en bedre kvalitet på begjæringene - hvilket i sin tur vil bidra til bedre rettssikkerhet og bedre behandling i Högsta domstolen. ${ }^{13}$

For det andre ble sammensetningen av retten i gjenåpningssaker forenklet i 2018, med ikrafttredelse $\mathrm{i}$ 2019. I noen saker kan saken avgjøres av én dommer, i stedet for tre som er hovedregelen, jf. RB 2 kap. $10 \S$ :

«Ett ärende som gäller extraordinärt ändringssökande kan i högsta domstolen behandlas och avgöras också i en sammansättning med tre ledamöter, om sammansättningen är enig om avgörandet.

En ledamot kan ensam

1) avvisa en i 31 kap. 19 § avsedd ny ansökan om extraordinärt ändringssökande i samma ärende,

2) avvisa en ansökan som gäller klagan på grund av domvilla eller återbrytande av dom, om sökanden inte har anlitat rättegångsombud eller rättegångsbiträde i enlighet med 15 kap. 1 § mom.,

\footnotetext{
${ }^{10}$ Tuomas Hupli, Johanna Niemi og Ulriikka Tammi, Extraordinärt ändringssökande i Finland, upublisert manus, 2020.

${ }^{11}$ RP 200/2017 rd s. 21.

${ }^{12} \mathrm{HD}: 2014: 77$.

${ }^{13}$ RP 318/2010 rd s. 21.
} 
3) behandla och avgöra ett ärende, om ansökan om extraordinärt ändringssökande har återtagits helt,

4) besluta om en särskild åtgärd, om en säkringsåtgärd, om förbud mot eller avbrytande av

verkställighet och om andra interimistiska åtgärder som gäller extraordinärt ändringssökande.»

For det tredje ble det i 2019 innført en begrensning i antall begjæringer. Av forarbeidene fremgår: ${ }^{14}$

«[E]n ledamot kan ensam avslå eller avvisa en ansökan om extraordinärt ändringssökande, om högsta domstolen redan tidigare har avslagit eller avvisat en ansökan i samma ärende och det inte läggs fram sådant nytt material, dvs. sådana nya omständigheter eller bevis, som stöder den nya ansökan.»

Videre RB 31 kap. 19 §:

«En part får hos högsta domstolen [...] ansöka om återbrytande av dom [...] endast en gång i samma ärende, om det inte av synnerligen vägande skäl är nödvändigt att pröva ärendet på nytt.»

Bestemmelsen begrenser således «flerdubbla ansökningar» om gjenåpning. Det finnes imidlertid en ventil: ${ }^{15}$

«En ny ansökan om extraordinärt ändringssökande i samma ärende kan dock prövas, om t.ex. sökandens rättssäkerhet absolut kräver att ärendet omprövas eller att det kommer fram att den första ansökan har förkastats på fel grunder.»

For det fjerde ble det fra 1. januar 2019 innført en mindre reform som delegerte gjenåpningsbegjæringer gjeldende endring av bot på grunn av innkomsttap til den opprinnelige domstolen, jf. 31 kap. 14 a $\S 1 \mathrm{a} .{ }^{16}$ Advokatkravet i RB 15 kap. $1 \S 4$ avsnitt gjelder ikke i disse saker.

Disse fire grepene i Finland som hadde til formål å begrense antallet begjæringer om gjenåpning, herunder «mångfaldigt ändringssökande», førte til at antall begjæringer falt med halvparten til cirka 180 saker per år. Til orientering mottar Gjenopptakelseskommisjonen cirka 160 saker per år. ${ }^{17}$

I Danmark synes repetitive begjæringer å være en ukjent problemstilling. Gorm Toftegaard Nielsen, ${ }^{18}$ som har vært medlem av den danske Klageretten, har ikke i løpet av sine 10 år opplevd dette mer enn muligens noen meget få ganger. «Hvis det ikke er nyt kød på sagen vil 1. voterende hurtigt finde ud af det og vi vil nok støtte os helt til ham. Jeg tror, at sekretariatet i givet fald ville medsende deres vota i den tidligere sag.» ${ }^{19}$ Problemstillingen er heller ikke nevnt i den danske litteraturen vedrørende Klageretten. Siden det ikke er dokumentert noe som ligner den norske iveren hva gjelder gjenåpningsbegjæringer, så kan det enten skyldes en kulturforskjell mellom advokatstanden i de to landene,${ }^{20}$ eller at Klageretten gjenåpner de riktige sakene. Det siste er det vanskelig for meg å mene noe om. Gjenåpningsprosenten er imidlertid mye lavere i Danmark enn i Norge - hvilket skulle tyde på at det er vanskeligere å få medhold i sin begjæring i Danmark enn i Norge. Tross dette er det altså færre antall «ombegjæringer». I Danmark er det imidlertid en tidsfrist for én sakstype: Dersom det anføres at det «i øvrigt foreligger særlige omstendigheter, der gjør det overveiende sandsynlig, at de foreliggende bevisligheder ikke har vært rigtigt

${ }^{14}$ RP 200/2017 rd.

${ }^{15}$ RP 200/2017 rd s. 43.

${ }^{16}$ Lag 13.6.2018/439.

${ }^{17}$ Gjenopptakelseskommisjonen, Årsrapport 2019.

${ }^{18}$ Gorm Toftegaard Nielsen er professor emeritus ved Aarhus Universitet. Tidligere professor i strafferett og straffeprosess samme sted. Se også Toftegaard Nielsen, Genoptagelse af straffesager. Danmark, upublisert manus, 2020.

${ }^{19}$ Personlig meddelelse til forfatteren.

${ }^{20}$ Forskjellen mellom nordiske advokaters holdninger til forskjellige spørsmål er etter min mening verdt et eget studium. 
bedømt» (rettspleieloven $§ 977$ første avsnitt nr. 3), må begjæringen fremmes innen fem år etter domsavsigelsen ( 9979 første avsnitt). ${ }^{21}$

Repetitive begjæringer forekommer også i Sverige. I de data Moa Lidén ${ }^{22}$ har samlet inn for perioden 2010-2019, har hun funnet 51 individer som har søkt gjenåpning flere ganger. ${ }^{23}$ «Rekordet» er 34 begjæringer i samme sak. De fleste av dem kommer fra individer uten rettslig bistand. For noen av begjæringene er det imidlertid åpenbart at de måtte avvises fordi begjæringen er ufullstendig eller ubehjelpelig. Søkere uten advokat klarer sjelden å formidle de grunner som begjæringen er basert på. Enkelte individer har ikke nok kompetanse for dette og trenger derfor veiledning og helst bistand fra en jurist. I disse tilfellene kan man anta at det hadde hjulpet med en rettshjelper, jamfør de finske argumentene for ombudstvang.

Også i Sverige forekommer repetitive begjæringer med bistand av advokat. Disse begjæringene er som regel fokusert enten på hva som er «nytt», eller de «synnerliga skäl» som anføres.

Om begjæringen er en gjentakelse / en kopi av tidligere begjæring som har blitt avslått, så kan man bli straffet for rettergangsforseelse.

Island har helt nylig etablert en spesialdomstol for gjenåpningssaker. Antallet begjæringer er meget få, mellom to og tre per år. Lovgivningen legger ikke noe hinder i veien for repetitive begjæringer siden det ikke er noen tidsfrister eller begrensninger på antallet begjæringer. ${ }^{24}$ Den eldste gjenåpnede saken på Island er fra 1980.

\section{Lovforslag}

I Norge er ufullstendige begjæringer ikke et problem, slik som i Finland og Sverige, siden Kommisjonen har plikt til å veilede den som begjærer gjenåpning, jf. § 397 første ledd. Kommisjonen kan også oppnevne offentlig forsvarer når særlige grunner tilsier det, som for eksempel for utilregnelige søkere eller søkere som bor langt unna Oslo. Det er også sjelden at begjæringen er en blåkopi av en tidligere begjæring. Som regel er det alltid en ny vinkel på de tekniske eller medisinske bevis som presenteres som en ny grunn for gjenåpning. Det går stort sett alltid å finne en sakkyndig i inn- eller utland som kan bidra med et nytt blikk eller ny viten. Om den nye vurderingen av et tidligere anført bevis er et nytt bevis «som synes egnet til å føre til frifinnelse», blir Kommisjonens vurderingstema. Av hensyn til rettssikkerheten og den domfelte er det derfor, etter mitt syn, verken mulig eller ønskelig å lukke døren helt for nye begjæringer, men det vil av hensyn til de pårørende og Kommisjonens ressursbruk, og dermed andre domfelte som søker om gjenåpning, være en fordel om antallet repetitive begjæringer ble begrenset.

${ }^{21}$ Dersom domfelte har vært underkastet frihetsberøvelse, kan begjæring om gjenåpning etter nr. 3 fremsettes inntil to år etter løslatelse, $\S 979$.

${ }^{22}$ Moa Lidén er post doc-forsker. Hun har doktorgrad i rettsfilosofi (allmän rättslära) fra Institutt for rettsvitenskap, Uppsala universitet, Sverige. Hennes forskning kaster lys over feilkilder i menneskets beslutninger og hvordan dette er relatert til f.eks. uriktige domfellelser. Hun har også publisert artikler om svensk gjenåpning av straffesaker.

${ }^{23}$ Moa Lidén, Resning i brottmål i Sverige, upublisert manus, 2020. «Quite commonly, the same individual applied lots of times. Many of these petitions referred to the same grounds as in previous petitions, which were sometimes not legally relevant at all and if they were relevant they were not sufficiently clear and supported by evidence.» (Moa Lidén, Linda Gräns og Peter Juslin, «Self-correction of wrongful convictions: is there a «System-level» confirmation bias in the Swedish legal system's appeal procedure for criminal cases? Part II», Law, Probability and Risk 17, 2018 s. 337-356.)

${ }^{24}$ Thordis Ingadottir og Kristín Haraldsdóttir, Reykjavik University, Reopening of criminal cases, Iceland, upublisert manus, 2020. 
En begrensende faktor kunne være å være strengere med erstatningsansvaret, jf. strpl. § 436 annet ledd. Imidlertid, Gjenopptakelseskommisjonen har per dags dato aldri pålagt noen å dekke sakens kostnader. ${ }^{25}$

Det ser heller ikke ut til at pålegg om bruk av advokat i Norge skulle begrense antallet repetitive begjæringer siden det nettopp er domfelte med advokat som står for disse begjæringene. I noen tilfeller med ny advokat. Å bare tillate én begjæring, etter den finske modellen, er en vanskelig vei å gå siden nye søknader gjerne omformuleres slik at de ved første gjennomlesing ser ut til å ha noen nye momenter som må prøves mot vilkåret om at «sökandens rättssäkerhet absolut kräver att ärendet omprövas». Det finske kravet i RB 31. kap. 19 § må uansett ha et unntak for tilfeller der det er svært tungtveiende grunner som tilsier en ny vurdering, når det $i$ lys av helt nye bevis er rimelig klart at dommen er uriktig.

Den eneste farbare veien, etter min mening, er å skjerpe kravene for gjenåpning etter noen få avviste begjæringer. Spørsmålet blir da: Hvor raskt skal skranken inntre, og hvor høy bør terskelen være? Altså ikke en tidsfrist etter rettskraftig dom slik Straffeprosesslovutvalget foreslår. Strengere krav ved nye begjæringer i samme sak burde inspirere domfelte/advokatene til å skrive klare, spissede, veldokumenterte begjæringer, aller helst ved første begjæring, men i hvert fall etter begrunnet avslag fra Gjenopptakelseskommisjonen.

Forslaget innebærer at rettssikkerheten til uriktig domfelte vil bli redusert i noen grad. Likevel vil rettssikkerheten være tilstrekkelig ivaretatt ved at domfelte fortsatt gis flere muligheter til å få rettet opp en uriktig dom.

${ }^{25}$ Meddelelse i e-post 20. august 2020 fra E. Kjærheim, Gjenopptakelseskommisjonen. 